\title{
Cytokine Release and Focal Adhesion Proteins in Normal Thyroid Cells Cultured on the Random Positioning Machine
}

\author{
Elisabeth Warnke ${ }^{a}$ Jessica Pietsch ${ }^{a}$ Sascha Kopp ${ }^{a}$ Johann Bauer \\ Jayashree Sahanac Markus Wehland ${ }^{a}$ Marcus Krüger ${ }^{a}$ Ruth Hemmersbach ${ }^{d}$ \\ Manfred Infanger ${ }^{a}$ Ronald Lützenberg ${ }^{a}$ Daniela Grimm ${ }^{a, c}$
}

${ }^{a}$ Clinic for Plastic, Aesthetic and Hand Surgery, Otto-von-Guericke-University Magdeburg, Magdeburg, Germany; ' Max-Planck Institute of Biochemistry, Martinsried, Germany; 'Institute of Biomedicine, Pharmacology, Aarhus University, Aarhus, Denmark; dDLR, German Aerospace Centre, Institute of Aerospace Medicine, Gravitational Biology, Cologne, Germany

\section{Key Words}

Thyroid • Multicellular spheroids $•$ Cytokines $•$ Focal adhesion • Extracellular matrix proteins • Pathway analyses

\begin{abstract}
Background/Aims: Spaceflight impacts on the function of the thyroid gland in vivo. In vitro normal and malignant thyrocytes assemble in part to multicellular spheroids (MCS) after exposure to the random positioning machine (RPM), while a number of cells remain adherent (AD). We aim to elucidate possible differences between AD and MCS cells compared to $1 \mathrm{~g}$-controls of normal human thyroid cells. Methods: Cells of the human follicular epithelial thyroid cell line Nthy-ori 3-1 were incubated for up to $72 \mathrm{~h}$ on the RPM. Afterwards, they were investigated by phase-contrast microscopy, quantitative real-time PCR and by determination of cytokines released in their supernatants. Results: A significant up-regulation of IL6, IL8 and CCL2 gene expression was found after a 4h RPM-exposure, when the whole population was still growing adherently. MCS and AD cells were detected after $24 \mathrm{~h}$ on the RPM. At this time, a significantly reduced gene expression in MCS compared to $1 \mathrm{~g}$-controls was visible for IL6, IL8, FN1, ITGB1, LAMA1, CCL2, and TLN1. After a 72 h RPM-exposure, IL-6, IL-8, and TIMP-1 secretion rates were increased significantly. Conclusion: Normal thyrocytes form MCS within $24 \mathrm{~h}$. Cytokines seem to be involved in the initiation of MCS formation via focal adhesion proteins.

(C) 2017 The Author(s)

Published by S. Karger AG, Basel
\end{abstract}

\section{Introduction}

Long-term space missions are a challenge for the health of crewmembers. There are reports about various health concerns such as dysfunctions of the musculoskeletal and cardiovascular system, a down-regulation of the immune system, and visual problems [13]. In space, the thyroid gland in vivo revealed a variety of changes such as follicles with

E. Warnke and J. Pietsch contributed equally to this manuscript.

Daniela Grimm

KARGER
Department of Biomedicine, Space Medicine, Aarhus University, Wilhelm Meyers Allé 4, DK-8000 Aarhus C, (Denmark)

Tel. +45-871 67693, Fax +45-8612 8804, E-Mail dgg@biomed.au.dk 
larger thyrocytes and increases in cAMP, thyrotropin-receptors (TSHR), and caveolin-1 [4, 5]. On the cellular level, it is known that both real $(\mathrm{r}-\mu \mathrm{g})$ and simulated microgravity (s$\mu g$ ) influence growth behaviour, gene expression pattern, protein synthesis and secretion in thyroid cancer cells [6-11]. In addition, thyroid hormone production is decreased, while a TSHR up-regulation was detected in follicular thyroid cancer cells after exposure for $24 \mathrm{~h}$ to a random positioning machine (RPM) [12] - a device designed to simulate microgravity conditions $[13,14]$. As thyroid hormones produced by the thyroid gland are influencing the function of nearly every cell and organ of the human body $[15,16]$, thyroid cells cultured under microgravity justify a thorough investigation. Therefore, the research was extended to normal thyrocytes.

Culturing normal thyroid cells in a rotary cell culture system (RCCS), three-dimensional (3D) cell aggregates resembling thyroid follicles were observed exhibiting the ability to produce thyroglobulin [17]. Rat FRTL-5 thyroid cells were investigated in $r-\mu g$ during a TEXUS rocket flight. The cells did not respond to thyrotropin (TSH) treatment and exhibited an irregular shape with condensed chromatin, shedding of the TSHR in the supernatant, and elevated protein levels of sphingomyelin-synthase and Bax [18]. Mice exposed to hypergravity treatment revealed up-regulation of the TSHR and caveolin-1 as well as a down-regulation of STAT3 without changes in cAMP [19].

Earlier experiments have shown that human thyroid cancer cells exhibit changes in the secretion of growth factors and cytokines, as well as alterations in the factors involved in 3D growth, in the cytoskeleton, and in the extracellular matrix composition when cultured in a an RPM $[10,20,21]$. Furthermore, human thyroid cells may exhibit two phenotypes in $s-\mu g$ either in the form of multicellular spheroids (MCS) or as adherent monolayer (AD) cells [20, 21].

For the present study, the human follicular epithelial thyroid cell line Nthy-ori 3-1 was exposed for $4 \mathrm{~h}, 24 \mathrm{~h}$ and $72 \mathrm{~h}$ to the RPM. MCS and AD cells were investigated in comparison to static $1 g$-controls. For this purpose, phase-contrast images were taken to monitor expected changes in the morphology of the thyrocytes. Furthermore, quantitative real-time PCR (qPCR) and multi-analyte profiling (MAP) analyses were performed. The chosen genes and cytokines were detected previously to have changed in cells of this cell line in $s-\mu g$ after RPM-exposure of 7 and 14 days [21]. The principal aim of these experiments was to close the knowledge gap concerning the impact of microgravity on the behaviour of normal thyroid cells exposed for a short time to s- $\mu g$ generated by an RPM.

\section{Materials and Methods}

Culture of Nthy-ori 3-1 cells

The Nthy-ori 3-1 cell line (Sigma-Aldrich, Munich, Germany) is a primary human thyroid follicular epithelial cell line. The immortalised cell line exhibits thyroid specific functions, such as iodide-trapping and thyroglobulin synthesis and reveals no signs of tumorigenesis, when transplanted into nude mice [22].

The Nthy-ori 3-1 cells were cultured under standard cell culture conditions $\left(37^{\circ} \mathrm{C}\right.$ and $\left.5 \% \mathrm{CO}_{2}\right)$. The cells grew in RPMI 1640 medium (Life Technologies, Naerum, Denmark), supplemented with $1 \%$ penicillin/ streptomycin (Life Technologies) and $10 \%$ (v/v) fetal calf serum (FCS) (Biochrom, Berlin, Germany). The cells were cultured in T25 $\mathrm{cm}^{2}$ vented cell culture flasks (Sarstedt, Newton, USA) for one day prior to RPMexposure. Each flask was seeded with $1 \times 10^{6}$ cells. The culture flasks were filled completely with medium without any air bubbles. The flasks ( $\mathrm{n}=60$ per time point) were assigned randomly to use as static controls $(1 g ; \mathrm{n}=30)$ or as RPM-samples $(\mathrm{n}=30)$. The $1 g$-controls were positioned next to the RPM in the same incubator. Supernatants and cells were harvested after $4 \mathrm{~h}, 24 \mathrm{~h}$ or $72 \mathrm{~h}$ according to the protocol.

Random positioning machine (RPM)

The Desktop RPM manufactured by Airbus Defense \& Space (ADS, Leyden, The Netherlands) was used for the simulation of microgravity [23]. The device was stored in an incubator at $37^{\circ} \mathrm{C}$ and $5 \% \mathrm{CO}_{2}$, operated in real random direction mode at 60 degrees/s and equipped with T25 flasks. The flasks were fixed to the ground plate, giving a maximum distance of $7.5 \mathrm{~cm}$ from the centre of rotation.

\section{KARGER}




\section{Cellular Physiology and Biochemistry
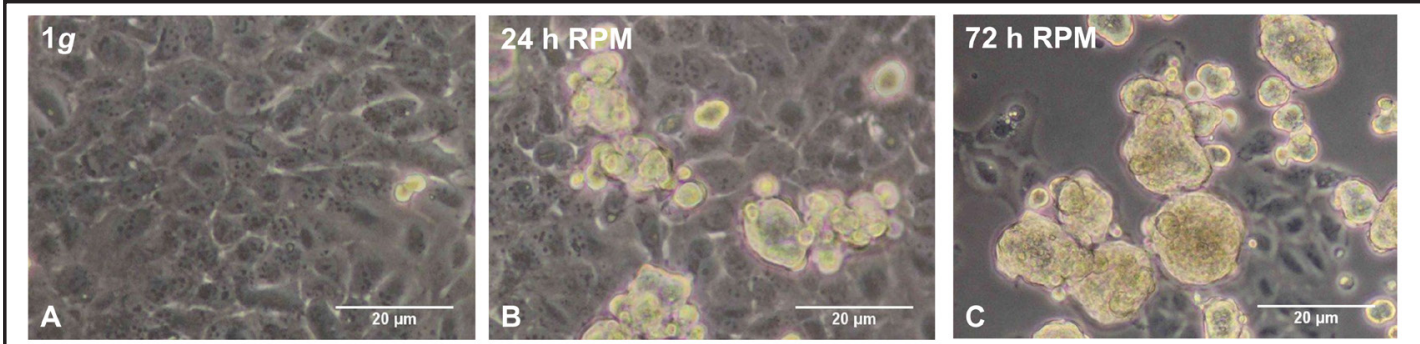

Fig. 1. Phase-contrast microscopy images of Nthy-ori 3-1 cells under $1 g$-conditions and after $24 \mathrm{~h}$ and $72 \mathrm{~h}$ of exposure to the RPM. Human thyrocytes of the cell line Nthy-ori 3-1 were exposed to the RPM for up to 72 h. Compared to $1 g$-controls (A), which showed only cells growing as adherent monolayers, cells exposed to $s-\mu g$ generated by the RPM showed no morphological differences after $4 \mathrm{~h}$ (data not shown), but started to detach and form 3D aggregates after a $24 \mathrm{~h}$ RPM-exposure (B). The MCS increased in number and size over time (72 h), while adherent cells decreased (C).

After the experimental run, cells and supernatants were harvested according to the protocol. The supernatants were collected and centrifuged at $4^{\circ} \mathrm{C}$ and $3000 \mathrm{rpm}$. Samples of $1.5 \mathrm{~mL}$ were transferred from the supernatants to $2 \mathrm{~mL}$ Eppendorf tubes (Eppendorf, Wesseling-Berzdorf, Germany) and frozen at $-80^{\circ} \mathrm{C}$ for MAP analyses. The pellet resulting from centrifugation contained the MCS. After removal of the supernatant, the MCS pellets were snap frozen in liquid nitrogen. AD cells were washed twice with PBS on ice, scraped off the bottom surface and transferred into a tube. After a centrifugation for $10 \mathrm{~min}$ at $3000 \mathrm{rpm}$ and $4^{\circ} \mathrm{C}$, the supernatant was discarded. The pellets were resuspended in $1 \mathrm{~mL}$ PBS and again centrifuged for $10 \mathrm{~min}$ at $3000 \mathrm{rpm}$ and $4^{\circ} \mathrm{C}$. The remaining supernatant was discarded carefully and the pellets with $\mathrm{AD}$ cells snap frozen in liquid nitrogen. Finally, the cells were stored at $-80^{\circ} \mathrm{C}$.

\section{Phase-contrast microscopy}

Phase-contrast microscopy was performed for visual observation of the cellular morphology, using the Leica Microscope (Leica Microsystems CMS GmbH, Germany). Pictures of RPM and control samples were taken after $4 \mathrm{~h}$ and $24 \mathrm{~h}$ (Fig. 1).

Cytokine measurements by multianalyte profiling (MAP) technology

Cytokines and proteins released into the supernatant were analysed by the company Myriad RBM (Austin, Texas, USA). The MAP analysis was performed using the Human CytokineMAP A and the KidneyMAP ${ }^{\circledR}$ as described previously [24-29]. Supernatants were taken after $4 \mathrm{~h}, 24 \mathrm{~h}$ and $72 \mathrm{~h}$ from $1 \mathrm{~g}$ - and RPM-samples ( $\mathrm{n}=9-10$; each group) and stored at $-80^{\circ} \mathrm{C}$ until shipment to Myriad RBM.

RNA isolation and quantitative real-time PCR ( $P P C R)$

RNA isolation was performed using the RNeasy Mini Kit (Qiagen, Hilden, Germany), with an additional DNase digestion step (Qiagen) in order to eliminate residual DNA contaminations. Subsequently, the amount of RNA was quantified via a Photometer Ultrospec2010 (Amersham Biosciences, Freiburg, Germany). The first strand cDNA synthesis kit (Thermo Fisher Scientific, Waltham, US) was used for reverse transcription. qPCR was performed using the 7500 Real-Time PCR System (Applied Biosystems, Darmstadt, Germany) according to routine protocols [30-32]. cDNA-selective-primers were synthesized by TIB Molbiol (Berlin, Germany) and are listed in Table 1 . The primers were designed using Primer Express (Applied Biosystems, Darmstadt, Germany) to have a $\mathrm{T}_{\mathrm{m}}$ of $\sim 60^{\circ} \mathrm{C}$ and to span exon-exon boundaries. All samples were measured in triplicate. For normalization, 18S rRNA

Table 1. Primers used for quantitative real-time PCR. All sequences are given in 5'-3' direction

\begin{tabular}{lll}
\hline Gene & Primer Name & Sequence \\
\hline 18S rRNA 18S-F & GGAGCCTGCGGCTTAATTT \\
\multirow{3}{*}{ FN1 } & 18S-R & GGAGCCTGCGGCTTAATTT \\
& FN1-F & AGATCTACCTGTACACCTTGAATGACA \\
IL6 & FN1-R & CATGATACCAGCAAGGAATTGG \\
& IL6-F & CGGGAACGAAAGAGAAGCTCTA \\
& IL6-R & GAGCAGCCCCAGGGAGAA \\
CXCL8 & CXCL8-F & TGGCAGCCTTCCTGATTTCT \\
& CXCL8-R & GGGTGGAAAGGTTTGGAGTATG \\
CCL2 & CCL2-F & GCTATAGAAGAATCACCAGCAGCAA \\
& CCL2-R & TGGAATCCTGAACCCACTTCTG \\
LAMA1 & LAMA1-F & TGCTCATGGTCAATGCTAATCTG \\
& LAMA1-R & TCTATCAATCCTCTTCCTTGGACAA \\
ITGB1 & ITGB1-F & GAAAACAGCGCATATCTGGAAAT \\
& ITGB1-R & CAGCCAATCAGTGATCCACAA \\
\multirow{2}{*}{ TLN1 1} & TLN1-F & GATGGCTATTACTCAGTACAGACAACTGA \\
& TLN1-R & CATAGTAGACTCCTCATCTCCTTCCA \\
\hline \multirow{2}{*}{ All sequences are given in 5'-3' direction }
\end{tabular}




\section{Cellular Physiology Cell Physiol Biochem 2017;43:257-270 \begin{tabular}{ll|l} 
DOI: 10.1159/000480368 & C 2017 The Author(s). Published by S. Karger AG, Basel \\
www.karger.com/cpb
\end{tabular} \\ Warnke et al.: Thyroid Cells on the Random Positioning Machine}

was used as a housekeeping gene. The comparative $\mathrm{C}_{\mathrm{T}}\left(\Delta \Delta \mathrm{C}_{\mathrm{T}}\right)$ method was used for relative quantification of transcription levels and $1 \mathrm{~g}$ was defined as $100 \%$ for reference.

Western blot analyses

Whole cell lysates were used for Western blotting following routine protocols for gel electrophoresis and trans-blotting, as described earlier [31,33]. Equal amounts of $10 \mu \mathrm{L}$ lysate containing $2 \mu \mathrm{g} / \mu \mathrm{L}$ protein were loaded on precast TGX stain-free gels (Bio-Rad, Munich, Germany). Transturbo blot PVDF membranes (Bio-Rad) were used for blotting. Each Western blot contained 5 samples for each group: $4 \mathrm{~h} 1 \mathrm{~g}, 4 \mathrm{~h}$ RPM-AD cells, $24 \mathrm{~h} 1 g, 24 \mathrm{~h}$ RPM AD cells and $24 \mathrm{~h}$ RPM MCS.

The following primary antibodies were used at a dilution of 1:1000: fibronectin (F3648), laminin (L9393) and talin (T3287) (all Sigma-Aldrich) and vascular endothelial growth factor (VEGFA; ab46154, Abcam, Cambridge, United Kingdom). The corresponding secondary antibodies were used at a dilution of 1:3000: HRP-linked anti-mouse IgG (\#7076) and anti-rabbit IgG (\#7074, both Cell Signaling Technology, Massachusetts, USA). The analysis was performed in ChemiDoc XRS+ (Bio-Rad), and the densitometric quantification was performed using ImageLab (BioRad).

Pathway Studio analysis

The commercially available Pathway Studio v.11 (Elsevier Research Solutions, Amsterdam, The Netherlands) was applied for the investigation of mutual regulation networks. For the analysis, SwissProt numbers of the investigated proteins were entered and networks built by the software based on relationships and processes from the literature, PubMed, databases and experimental data $[9,10,33]$.

\section{Statistical evaluation}

Statistical evaluation was performed with SPSS 15.0 (SPSS, Inc., Chicago, IL, USA) using the MannWhitney-U-Test. All data are presented as mean \pm standard deviation (SD) values and differences between groups were considered significant at $\mathrm{p}<0.05$.

\section{Results}

Multicellular spheroid (MCS) formation

Subconfluent monolayers of the human follicular epithelial thyroid cell line Nthy-ori 3-1 were exposed to the RPM or to $1 g$-control conditions. Both groups were located in parallel in the same incubator. After $4 \mathrm{~h}$, the cells of both RPM and $1 g$-controls groups showed solely adherent growth. MCS formation occurred within $24 \mathrm{~h}$ on the RPM (Fig. 1) while cells of the $1 g$-controls continued to grow as a $2 \mathrm{D}$ cell monolayer attached to the bottom of the culture flask. In RPM cultures, the mixture of AD cells and MCS remained for up to $72 \mathrm{~h}$ of RPM-exposure, although the number of AD cells appeared to decrease slightly. The two cell populations could be harvested separately from the RPM-samples according to the method described above.

Cytokine release of Nthy-ori 3-1 cells after RPM-exposure

Concentrations of selected cytokines within the various culture supernatants were determined by MAP analysis in order to estimate the secretion activities of the cells (Human CytokineMAP A and Human KidneyMAP ${ }^{\circledR}$, carried out by Myriad RBM). Table 2 shows all of the cytokines of these two MAPs, which could be detected.

Interleukin 6 (IL-6; IL6), interleukin 8 (IL-8; CXCL8), cystatin-c (CST3), tissue inhibitor of metalloproteinase (TIMP-1; TIMP1) and VEGF (VEGF) could be detected after $4 \mathrm{~h}$, whereas monocyte chemoattractant protein (MCP-1; CCL2) could only be detected after $24 \mathrm{~h}$ and 72 $\mathrm{h}$ and interleukin 7 (IL-7; IL7) could only be detected after $72 \mathrm{~h}$ and even then only in the RPM-samples.

Although these cytokines have been identified, only five of them revealed significant differences between $1 g$ and the respective RPM sample. Cystatin-c (CST3) and tissue inhibitor of metalloproteinase-1 (TIMP1) were reduced significantly in s- $\mu g$ compared to $1 g$ after $4 \mathrm{~h}$. 
Table 2. Cytokines released by Nthy-ori 3-1 cells after a 4 h-, 24 h- and 72 h-RPM-exposure, detected by Multi-Analyte Profiling using human CytokineMAP $\mathrm{A}^{\circledR}$ and human KidneyMAP ${ }^{\circledR}$

\begin{tabular}{|c|c|c|c|c|c|c|c|}
\hline \multirow[b]{2}{*}{ Factors } & \multirow[b]{2}{*}{$\begin{array}{c}\text { LDD } \\
(\mathrm{pg} / \mathrm{mL})\end{array}$} & \multicolumn{2}{|c|}{$4 \mathrm{~h}$} & \multicolumn{2}{|c|}{$24 \mathrm{~h}$} & \multicolumn{2}{|c|}{$72 \mathrm{~h}$} \\
\hline & & $\begin{array}{c}1 \mathrm{~g} \\
(\mathrm{pg} / \mathrm{mL})\end{array}$ & $\begin{array}{c}\text { RPM } \\
(\mathrm{pg} / \mathrm{mL})\end{array}$ & $\begin{array}{c}1 \mathrm{~g} \\
(\mathrm{pg} / \mathrm{mL})\end{array}$ & $\begin{array}{c}\text { RPM } \\
(\mathrm{pg} / \mathrm{mL})\end{array}$ & $\begin{array}{c}1 g \\
(\mathrm{pg} / \mathrm{mL})\end{array}$ & $\begin{array}{c}\mathrm{RPM} \\
(\mathrm{pg} / \mathrm{mL})\end{array}$ \\
\hline \multicolumn{8}{|c|}{ Human CytokineMAP A } \\
\hline IL-6 & 1.0 & 15.72 & 13.00 & 107.78 & 102.70 & 180.00 & 267.22 \\
\hline (ILG) & & \pm 9.12 & \pm 4.31 & \pm 39.98 & \pm 17.06 & \pm 26.45 & $\pm 34.13^{*}$ \\
\hline IL-7 & 6.1 & n.d. & n.d. & n.d. & n.d. & n.d. & 8.54 \\
\hline (IL7) & & & & & & & \pm 0.72 \\
\hline IL-8 & 0.56 & 37.9 & 30.4 & 324.6 & 224.8 & 468.4 & 642.3 \\
\hline$(C X C L B)$ & & \pm 19.47 & \pm 10.02 & \pm 177.32 & \pm 54.84 & \pm 92.08 & $\pm 176.16^{*}$ \\
\hline $\begin{array}{l}\text { MCP-1 } \\
\text { (CCL2) }\end{array}$ & 15 & n.d. & n.d. & $\begin{array}{r}112.22 \\
\pm 53.42\end{array}$ & $\begin{array}{c}66.89 \\
\pm 20.09\end{array}$ & $\begin{array}{r}433.56 \\
\pm 82.27\end{array}$ & $\begin{array}{c}441.1 \\
\pm 67.67\end{array}$ \\
\hline \multicolumn{8}{|c|}{ Human KidneyMAP® } \\
\hline $\begin{array}{l}\text { Cystatin-c } \\
\text { (CST3) }\end{array}$ & 20 & $\begin{array}{l}358.00 \\
\pm 87.6\end{array}$ & $\begin{array}{c}185.56 \\
\pm 35.00 *\end{array}$ & $\begin{array}{c}3,022.2 \\
\pm 739.04\end{array}$ & $\begin{array}{c}2,680.0 \\
\pm 727.74\end{array}$ & $\begin{array}{c}9,755.56 \\
\pm 1,101.63\end{array}$ & $\begin{array}{l}11,190.00 \\
\pm 1,781.2\end{array}$ \\
\hline $\begin{array}{l}\text { TIMP-1 } \\
\text { (TIMP1) }\end{array}$ & 6.1 & $\begin{array}{r}177.00 \\
\pm 44.73\end{array}$ & $\begin{array}{c}102.7 \\
\pm 20.78 *\end{array}$ & $\begin{array}{r}2,410.0 \\
\pm 811.73\end{array}$ & $\begin{array}{c}2,030.0 \\
\pm 376.96\end{array}$ & $\begin{array}{l}6,344.44 \\
\pm 869.36\end{array}$ & $\begin{array}{c}8,366.67 \\
\pm 1,531.89 *\end{array}$ \\
\hline $\begin{array}{l}\text { VEGF } \\
(V E G F A)\end{array}$ & 3.9 & $\begin{array}{l}12.07 \\
\pm 2.45\end{array}$ & $\begin{array}{l}10.85 \\
\pm 2.39\end{array}$ & $\begin{array}{r}110.00 \\
\pm 36.33\end{array}$ & $\begin{array}{c}124.6 \\
\pm 38.71\end{array}$ & $\begin{array}{r}328.56 \\
\pm 56.35\end{array}$ & $\begin{array}{c}359.5 \\
\pm 72.24\end{array}$ \\
\hline
\end{tabular}

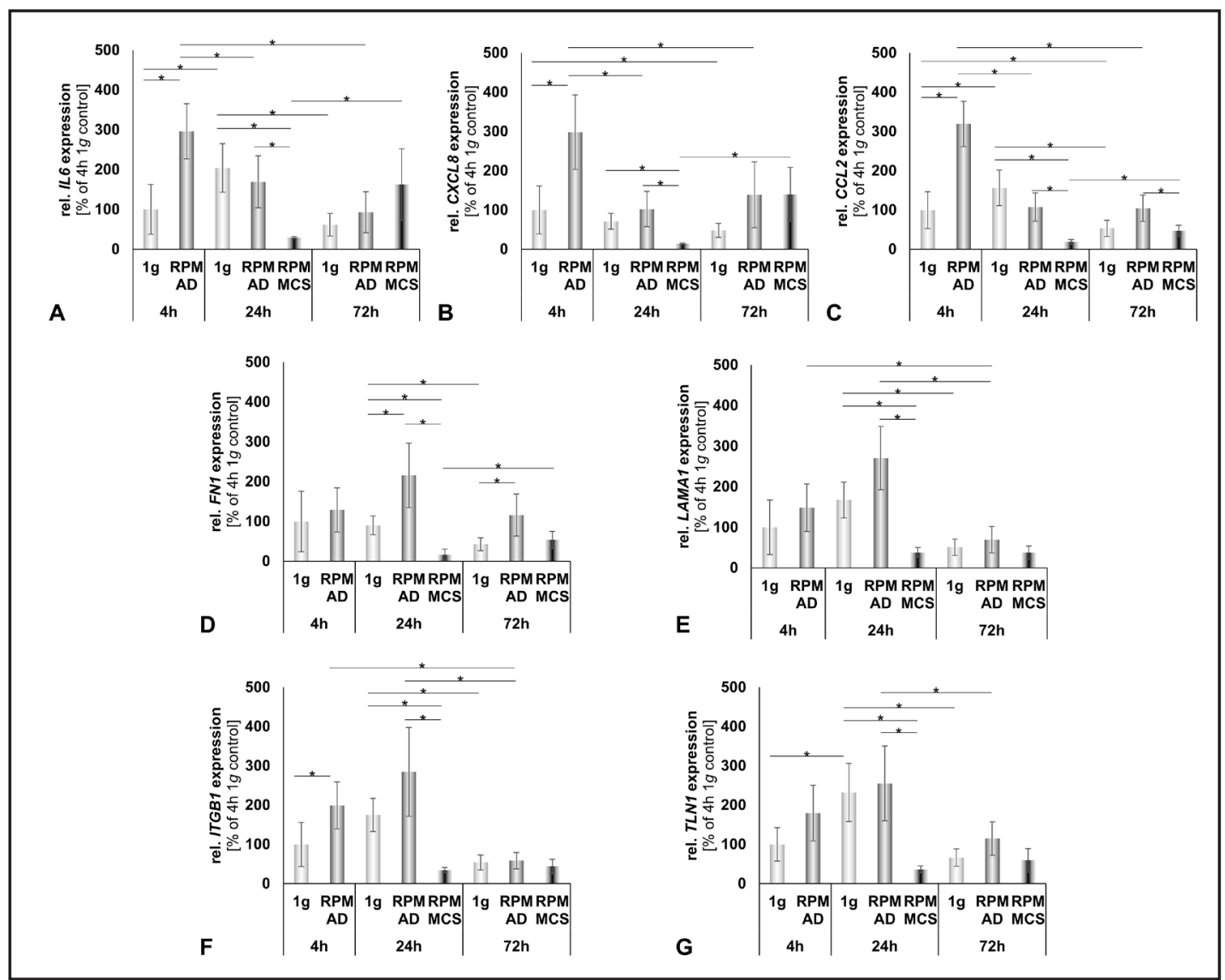

Fig. 2. Quantitative real-time PCR (qPCR) was used to determine the gene expression. The gene expression levels of IL6 (A), CXCL8 (B), CCL2 (C), FN1 (D), LAMA1 (E), ITGB1 (F), and TLN1 (G) were measured after 4 $\mathrm{h}, 24 \mathrm{~h}$ and $72 \mathrm{~h}$ RPM-exposure and in corresponding $1 \mathrm{~g}$-controls. All values were expressed relative to the value for $4 \mathrm{~h}$ of $1 \mathrm{~g}$, which was set to $100 \%$ and all other values are expressed relative to this value. $1 g$-static control; RPM - random positioning machine; AD - adherent cells; MCS - multicellular spheroids; $\mathrm{n}=5-6$; $*-\mathrm{p}<0.05$.

After $24 \mathrm{~h}$ RPM-exposure, no significant changes could be observed. However, after $72 \mathrm{~h}$, IL-6 (IL6), IL-8 (CXCL8) as well as TIMP-1 (TIMP1) were elevated significantly in s- $\mu g$ compared to $1 g$-controls. 
Altered gene expression in Nthy-ori 3-1 cells exposed to the RPM

Changes in the mRNA expression levels of IL6, CXCL8 and CCL2 were investigated by qPCR (Fig. 2A-C). This revealed a significant increase between $1 g$ - control cells and RPM$\mathrm{AD}$ cells that had been exposed for $4 \mathrm{~h}$. However, these increases in gene expression were already equalized after $24 \mathrm{~h}$. Interestingly, the gene expression was decreased significantly after $24 \mathrm{~h}$ in RPM-MCS samples compared to $1 g$-controls as well as RPM-AD samples. For IL6 and CXCL8 no significant alterations were detectable after RPM-exposure for $72 \mathrm{~h}$. CCL2 gene expression was only reduced significantly compared to RPM-AD samples, but not compared to $1 g$-controls.

Furthermore, we focused on the genes coding for fibronectin (FN1), laminin (LAMA1), $\beta_{1}$-integrin (ITGB1), and talin (TLN1), as these are involved in focal adhesion processes. Only ITGB1 showed a significantly increased gene expression in RPM-AD samples compared to $1 g$-controls after $4 \mathrm{~h}$ (Fig. $2 \mathrm{~F}$ ). The other three genes revealed no significant changes at this time point (Fig. 2D, E and G). However, $24 \mathrm{~h}$ of RPM exposure triggered a significantly elevated expression in FN1 in RPM-AD samples compared to $1 g$-controls and MCS, while TLN1, ITGB1 and LAMA1 were up-regulated significantly in RPM-AD samples compared to RPM-MCS samples only, but were expressed similarly in $1 g$-control samples. After RPMexposure for $72 \mathrm{~h}$, only a significant increase in RPM-AD samples compared to $1 \mathrm{~g}$ controls could be detected for FN1 expression level (Fig. 2D).

\section{Content of selected proteins after RPM-exposure}

After focusing on gene expression changes, we studied the ECM and cell adhesion molecules laminin, fibronectin and talin-1 (Fig. 3A, B, and D). The amount of laminin was similar in cells exposed for $4 \mathrm{~h}$ to the RPM, but increased after $24 \mathrm{~h}$. There was no significant difference in the laminin protein content after a $24 \mathrm{~h}$-exposure (Fig. 3A). Also, the fibronectin accumulation was approximately equal in samples incubated for $4 \mathrm{~h}$. After $24 \mathrm{~h}$, both, the RPM-AD cells and the RPM-MCS cells exhibited increased amounts of fibronectin (Fig. 3B). Talin-1, which links integrins to the actin cytoskeleton has been shown to be increased slightly in MCS compared to $1 g$ and AD cells after RPM-exposure for $24 \mathrm{~h}$. VEGF was released into the supernatant and was unaltered in $1 g$-control cells of thyrocytes cultured for $4 \mathrm{~h}$ on the RPM, while RPM-AD cells that had been exposed for $24 \mathrm{~h}$ exhibited a lower VEGF content. There was no difference in VEGF content between MCS and $1 g$-control cells (Fig. 3C).

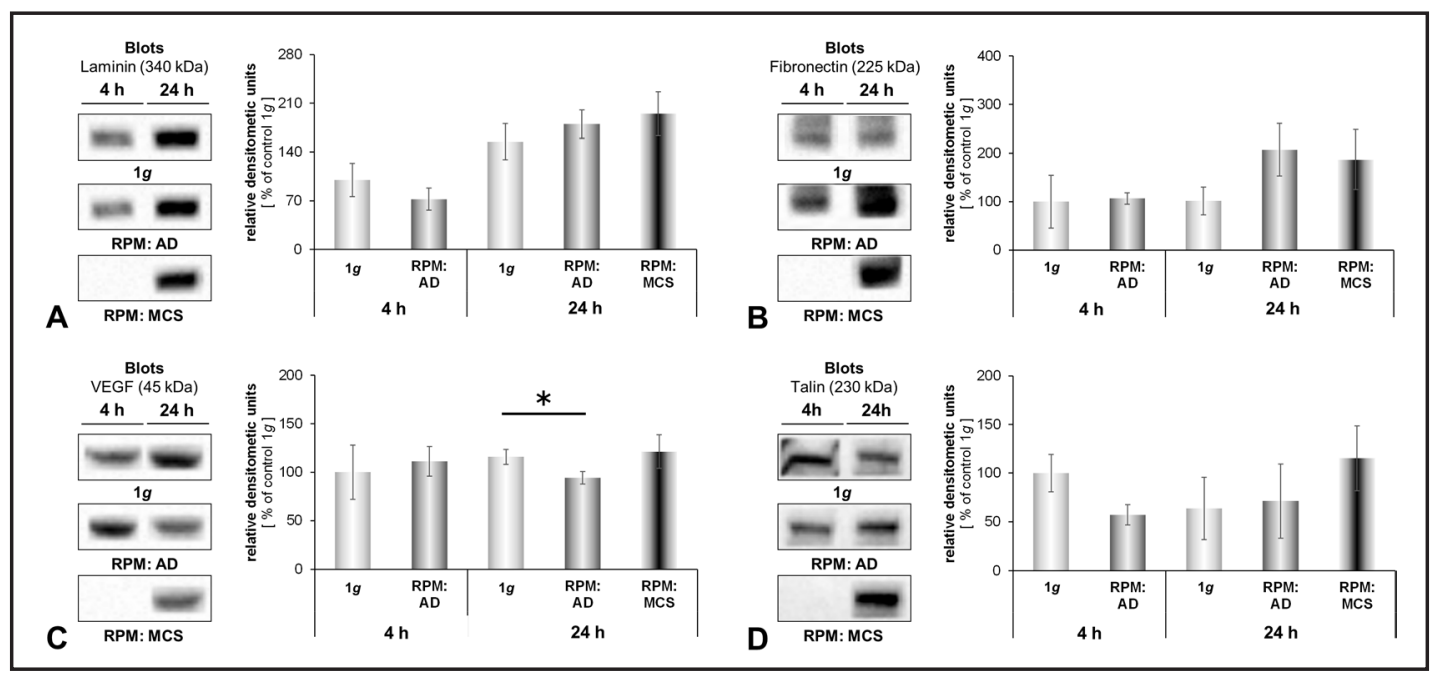

Fig. 3. Content of cell adhesion proteins, VEGF and talin. Nthy-ori 3-1 cells were harvested after $4 \mathrm{~h}$ and 24 $\mathrm{h}$ of exposure to the RPM or as corresponding $1 g$-controls. The protein contents of laminin (A), fibronectin (B), VEGF (C) and talin (D) were detected by Western blot analyses. Static $1 g$-control (1g); random positioning machine (RPM); adherent cells (AD); multicellular spheroids (MCS); $\mathrm{n}=5$; * $\mathrm{p}<0.05$ vs. $1 g$-control. 


\section{$\begin{array}{ll}\text { Cellular Physiology Cell Physiol Biochem 2017;43:257-270 } \\ \text { DOI: 10.1159/000480368 } & 0 \text { 2017 The Author(s). Published by S. Karger AG, Basel }\end{array}$

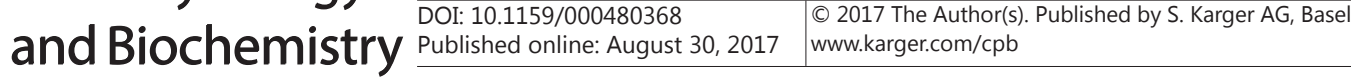

Warnke et al.: Thyroid Cells on the Random Positioning Machine

Pathway Analyses

Searching related information via Pathway Studio, proteins of differentially expressed genes and proteins detected in the supernatant of Nthy-ori 3-1 cells were investigated with respect to their cellular localization and their interaction on the protein level (Fig. 4) as well as in regard to their mutual influence on the genetic level (Fig. 5). The cohort of proteins analysed includes the extracellular proteins laminin A1 and fibronectin, the membrane proteins integrin- $\beta_{1}$ and talin- 1 . These four proteins can bind to each other as shown by the solid lines in Fig. 4 [34,35]. Their stability is enhanced by a direct interaction with TIMP1 [36] and via an indirect positive action by IL-8 [37]. IL-7 and VEGF also have an influence on the ITGB1, LAMA1, FN1, TLN1 complex [38-40], while IL-6, MCP-1 and cystatin c do not appear to make contact with this complex.

On the gene level LAMA1 is isolated from the genes of the other soluble and membranebound proteins investigated (Fig. 5). Like VEGFA, IL-6 and MCP-1 have positive regulatory effects on the genes of ITGB1 and FN1 [41-45]. IL-8 can up-regulate FN1 expression [46]. CXCL8 and CCL2 genes are also up-regulated by VEGF and IL-6 $[47,48]$, while TLN1 is downregulated by IL- 6 and IL-8 [49]. In addition, cystatin c affects turnover of fibronectin [50] and IL-7 regulates the expression of CCL2 and CXCL8 [51].

Fig. 4. Mutual interaction and localization of the 11 investigated proteins. Interaction and localization of cytokines observed in cell culture supernatants (Table 2) and of proteins whose genes were sensitive to exposure to the RPM (Fig. 2). Solid lines indicate binding, solid arrows show directed interaction, dashed arrows show influence. + signs point to an activity enhancing effect. The interaction network was built up using Pathway Studio v.11.

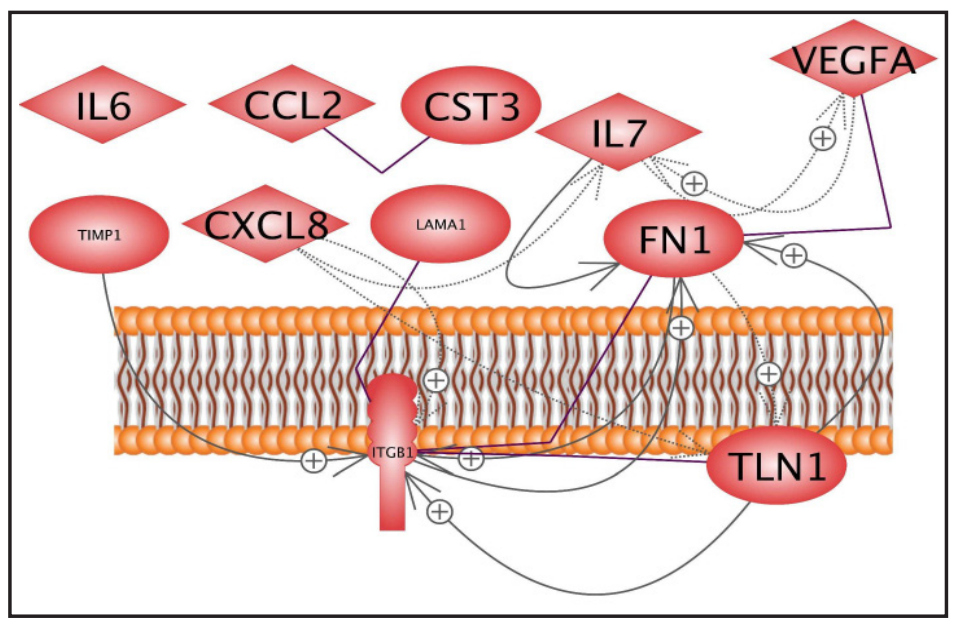

Fig. 5. Mutual interaction of selected genes at the gene expression level. Selected genes, whose upor down-regulation were analysed by qPCR after RPM-exposure as shown in Fig. 2 together with the genes of the proteins secreted into the supernatant as shown in Table 2. The arrows indicate influence. Arrows with + sign indicate up-regulation, while lines with crossbars at the end show downregulation. The interaction network was built up using Pathway Studio v.11.

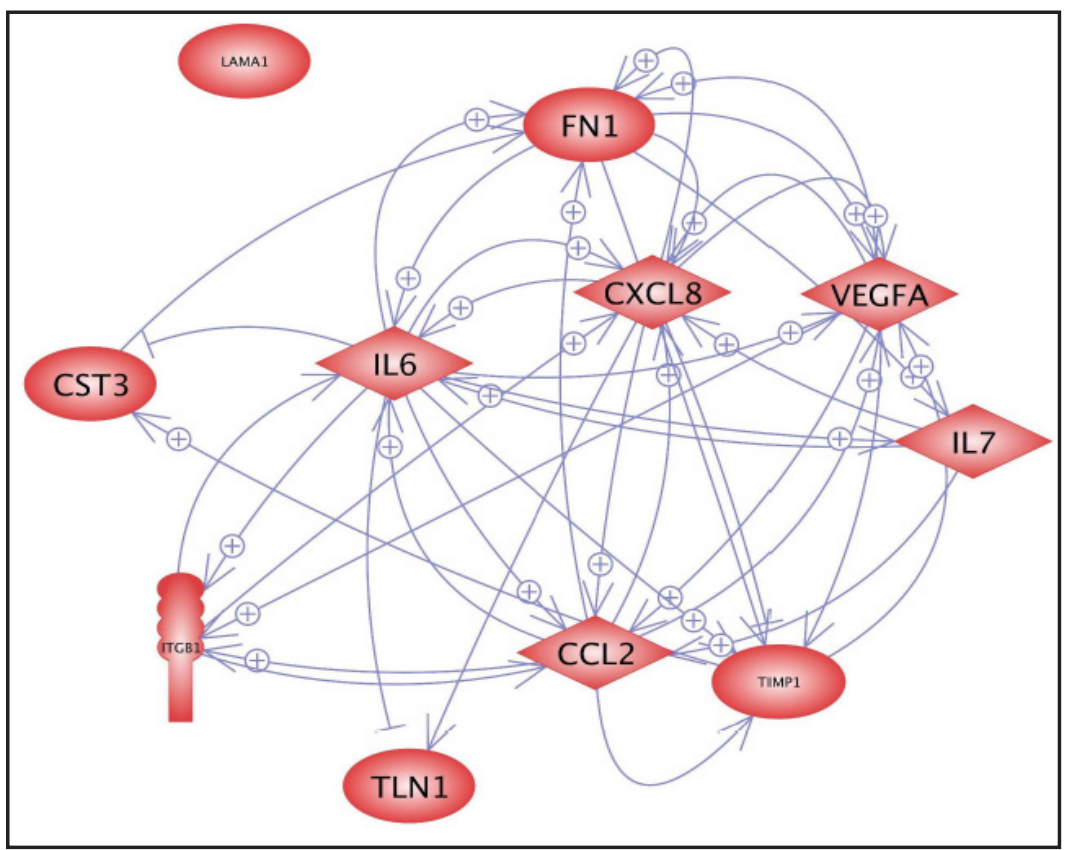




\section{Cellular Physiology Cell Physiol Biochem 2017;43:257-270 \\ \begin{tabular}{ll|l} 
DOI: 10.1159/000480368 & O 2017 The Author(s). Published by S. Karger AG, Basel \\
www.karger.com/cpb
\end{tabular} \\ Warnke et al.: Thyroid Cells on the Random Positioning Machine}

\section{Discussion}

In this study, we investigated the morphological and molecular biological changes of normal human thyrocytes (Nthy-ori 3-1 cell line) exposed for $4 \mathrm{~h}, 24 \mathrm{~h}$ and $72 \mathrm{~h}$ to a an RPM. The objective of this project was to monitor changes occurring during short-term RPM-exposure in normal human thyrocytes with respect to the influence of soluble factors on proteins involved in focal adhesion. These findings might help to further understand the observed impact of microgravity on the formation of 3D aggregates of normal human thyrocytes and other cells $[4,5]$.

\section{MCS formation}

One part of the RPM-exposed normal human thyroid cells of the Nthy-ori 3-1 cell line formed MCS, while the other part continued to grow adherently. The MCS became visible after $24 \mathrm{~h}$. This observation broadens the observation made by Kopp et al., who investigated MCS after 7 and 14 days [21]. This early 3D growth is in agreement with the formation of cancer MCS by the thyroid cancer cells lines ML-1, FTC-133 and R082-W-1 [12, 21, 28, 49]. Like the thyroid cancer cells FTC-133, the normal Nthy-ori 3-1 cells required a lag time of several hours of RPM-exposure, before some of the cells started to detach from the bottom of the culture flask and to assemble to 3D aggregates [28], while others remained adherent. Hence, regarding the morphological changes triggered by s- $\mu g$, a striking difference between normal and cancer cells could not be detected.

Genes and proteins altered by RPM-exposure

Investigating cytokines, we found an influence of s- $\mu g$ on IL-6 (IL6) and IL-8 (CXCL8) at gene and protein secretion levels (Table 2, Fig. 2). The cytokines IL-6 and IL-8 are involved in angiogenesis and progression in different cancer types [52-54]. On the RPM, their genes were up-regulated significantly after $4 \mathrm{~h}$ in RPM-AD cells. However, after $24 \mathrm{~h}$ both were un-regulated again in RPM-AD cells, but were down-regulated significantly in MCS cells (Fig. 2 ). During the next $48 \mathrm{~h}$ a slight tendency of up-regulation in AD as well as MCS cells was observed although this was not significant (Fig. 2A, B). In parallel, the secretion of IL-6 and IL-8 into the supernatant did not reveal any alteration due to s- $\mu$ g until $72 \mathrm{~h}$ when both proteins were up-regulated significantly in RPM-exposed cells (Table 2).

IL-6 and IL-8 play a key role in angiogenesis and 3D growth in cancer [55, 56]. IL-6 induces the production of VEGF [57] and a similar function is assumed for IL-8 (Fig. 5). When secreted by U937 cells IL-8 induces the fibronectin expression by inflammatory breast cancer cells (SUM149 cell line) via interaction with IL-8 specific receptors and stimulation of the PI3K/Akt signalling pathway [46].

IL-6 and IL-8 influence the formation and growth of MCS established under $1 g$-conditions $[49,58]$. Recently, we demonstrated their direct impact using the liquid-overlay technique [49]. The cytokines IL-6 and IL-8 are strong regulators controlling FN1 and ITGB1 expression (Fig. 5). Furthermore, both cytokines were increased significantly in space samples of human thyroid cancer FTC-133 cells cultured in $r-\mu g$ conditions for 12 days on the International Space Station compared with $1 g$-controls [9]. However, in this case no MCS formation could be observed whereas during another spaceflight on which FTC-133 cells were grown for 10 days in $\mu g$ and MCS were formed, no differences between ground and space samples could be observed for IL-6 and only a slight decrease was observed for IL-8 [7]. How these findings can be explained regarding the role of IL- 6 and IL-8 in 3D growth has to be elucidated in future space experiments.

An important finding was the detection of IL-7 in the supernatant after RPM-exposure for $72 \mathrm{~h}$ (Table 2). Interestingly, control samples did not secrete IL-7. IL-7 is considered a powerful pro-inflammatory cytokine, which can induce tumorigenesis [59]. A variety of cells, for example intestinal epithelial cells, keratinocytes, hepatic tissue, endothelial cells, smooth muscle cells, fibroblasts, thyroid cancer cells and others, have proven to produce IL-7 [21,60]. IL-6 interacts with IL-7 and vice versa (Fig. 5). Together they have a regulatory influence on 
cell-cell adhesion of melanocytes [61], but no data exist concerning the interaction between IL-6 and IL-7 for normal thyroid cells. In our experiments the cells secreted IL-7 only after $72 \mathrm{~h}$ on the RPM, while the corresponding $1 g$-control cells did not secrete this cytokine at all. However, it could be shown that Nthy-ori 3-1 cells secrete IL-7 after 7 days when cultured under normal $1 g$-conditons and on the RPM [21].

In addition, IL-7 can influence ECM production and decrease fibronectin expression. This was shown in human subconjunctival fibroblasts [62]. In our experiments the FN1 gene expression was elevated in Nthy-ori 3-1 AD cells after RPM-exposure for $24 \mathrm{~h}$ compared with $1 g$-control cells, while the FN1 mRNA was down-regulated in MCS cells (Fig. 2A). After a $72 \mathrm{~h}$ RPM-exposure, the FN1 expression was still down-regulated in Nthy-ori 3-1 MCS compared to AD cells. This finding was paralleled by the secretion of IL-7 by the RPM-mounted thyroid cells after $72 \mathrm{~h}$ and might demonstrate a regulatory interaction of IL-7 with fibronectin (Fig. 4). In addition, these data suggest that the cytokine IL-7 might be a very likely key candidate involved in regulating MCS formation [21].

Integrins are transmembrane $\alpha$ - and $\beta$-subunit forming receptors for distinct ECM proteins, such as fibronectin, or laminin [63]. They mediate the cell adhesion to ECM components supporting adhesion of cells grown on two-dimensional surfaces and within three-dimensional matrices [64]. Although integrins consist of $\alpha$ - and $\beta$-subunit, incorporated $\beta_{1}$-integrin seems to play a special role increasing cell migration and invasion, and decreasing sensitivity to anti-cancer drug in triple-negative breast cancer [65]. Overexpression of $\beta_{1}$ integrin has been demonstrated to improve the activities and functions of several benign cell types [66]. For example, $r-\mu g$ during a parabolic flight induced $\beta_{1}$-integrin expression in human chondrocytes [67].

The role that laminin plays in MCS formation remains to be elucidated. However, it is a fact that laminins interact with several integrin isoforms and are involved in migration and development $[35,68]$. Moreover, since the gene expression of LAMA1 was down-regulated in MCS cells, an impact of this gene or protein seems to be very likely. Interestingly, laminin A1 was not detected in a recent proteome study, which revealed more than 5000 proteins of thyroid cancer cells [69]. Therefore, the presence of laminin A1 could be a sign of normal cell differentiation as was shown for human mesenchymal stem cells [70].

Talin (TLN1) is found in high concentrations in focal adhesions and links integrins to the actin cytoskeleton [71]. Due to its direct interaction with $\beta_{1}$-integrin (Fig. 4), we analysed the gene expression of TLN1. In Nthy-ori 3-1 cells, the TLN1 mRNA was found to be downregulated significantly in MCS after RPM-exposure for $24 \mathrm{~h}$, but without differences to normal gravity after 4 and $72 \mathrm{~h}$. It has been shown that TLN1 is involved in RPM-dependent thyroid carcinoma MCS formation [8]. Regarding the findings described above, the TLN1 gene expression might point to the time frame in which the detachment and subsequent formation of MCS occurs.

VEGF was detectable in Nthy-ori 3-1 cells and the secretion of VEGF increased over time in the supernatant (Table 2). No difference between $1 g$-controls and RPM-samples could be observed up until $72 \mathrm{~h}$. VEGF plays an important role in neoangiogenesis, proliferation and migration, mainly of endothelial cells but also of various other cells types [72-74]. VEGF seems to be affected considerably in thyroid cancer cells exposed to $s-\mu g[72,75]$. Furthermore, there might be a delayed response in Nthy-ori 3-1 cells, when exposed to s- $\mu g$. It could be shown that VEGF secretion was decreased after RPM-exposure for 7d [21].

The secretion of TIMP-1 was significantly lower after $4 \mathrm{~h}$ in RPM-samples compared with $1 g$-controls, whereas a 1.32-fold elevated amount of TIMP-1 was measured after $72 \mathrm{~h}$ in the supernatant of RPM-samples. TIMPs inhibit metalloproteinases, which in turn are widely known to degrade the ECM and thus participate in remodelling the shape and composition of cell aggregates and tissues [76, 77]. An overexpression of TIMP-1 was also implicated in several cancer types and correlated with a less-positive outcome for a patient after treatment [76]. A decreased expression of TIMP-1 seems to facilitate the detachment of the thyroid Nthy-ori 3-1 cells from the bottom of cell culture flasks in the early hours of RPM-exposure (Table 2) due to a failure to stabilize integrin- $\beta_{1}$ activity [36]. The later increase might be a

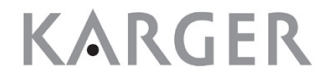


facilitator of cell-cell contacts during the rearrangement of the focal adhesion complex for 3D cell aggregate formation [69]. A similar influence could be observed in endothelial cells. Even after $7 \mathrm{~d}$ and $14 \mathrm{~d}$ of RPM-exposure, the amount of TIMP-1 was reduced significantly in $s-\mu g$ [24]. These data indicate the involvement of TIMP-1 in 3D formation of MCS, which contain a high amount of ECM proteins.

Cystatin-c is secreted as an extracellular polypeptide and functions biologically as a protease inhibitor. Dysregulated cystatin-c levels are implicated in various clinical diseases [78]. The secretion of cystatin-c was decreased significantly after $4 \mathrm{~h}$ of RPM-exposure. Later on, no differences between the different groups were evident. As cystatin-c was downregulated together with TIMP-1 a general inhibition of ECM degradation seems to be a result of microgravity. Further experiments should be conducted to verify this hypothesis.

MCP-1 is a key member of the large family of chemokines which regulate mainly cell trafficking. MCP-1 itself is associated with regulating migration and infiltration of monocytes/macrophages [79]. Many experiments were conducted focusing on MCP-1 and its involvement in various diseases like hypertension, inflammatory or neuronal diseases and cancer. A high or constitutive expression level of CCL2 is often observed [80-82]. The human thyroid Nthy-ori 3-1 cells secrete MCP-1 after $24 \mathrm{~h}$ in a continually increasing amount of MCP- 1 although no differences could be observed between normal gravity and s- $\mu g$. These findings are in accordance with the earlier results regarding MCP-1 in the supernatant of Nthy-ori 3-1 cells cultivated on the RPM for $7 \mathrm{~d}$ [21]. Whether this expression has an impact on the signal transduction or if the MCP-1 specific receptor CCR2 [83] is even expressed, remains to be elucidated.

\section{Conclusion}

The normal human thyroid cell line Nthy-ori 3-1 was shown to form MCS as early as 24 $\mathrm{h}$ after RPM-exposure. The secretion of several cytokines in connection with focal adhesion proteins paint a picture of entangled and positively or negatively interacting proteins which might strengthen the onset of the MCS formation. Further analyses will have to be performed to elucidate in more detail how these cytokines exert their effect. Though MCS formation is induced by exposing cells to an RPM, which is comparable to their behaviour in $r-\mu g$, our results indicate what might happen during a spaceflight. However, they have to be verified under this condition.

\section{Acknowledgements}

The authors would like to thank the German Space Agency (DLR; (DG) BMWi projects 50WB1124 and 50WB1524), Aarhus University, Denmark, and DGLRM (Young Fellow Program for EW). We would like to thank the team of PRS \& EJE Hertfordshire, UK, for academic proofreading of the manuscript. The funders had no role in study design, data collection and analysis, decision to publish, or preparation of the manuscript. EW is a doctoral candidate of the Helmholtz Space Life Sciences Research School, German Aerospace Centre Cologne, Germany. We like to thank the PhD school for support.

\section{Disclosure Statement}

The authors declare no competing financial interest.

\section{References}

1 White RJ, Averner M: Humans in space. Nature 2001;409:1115-1118.

2 Grimm D, Wise P, Lebert M, Richter P, Baatout S: How and why does the proteome respond to microgravity? Expert Rev Proteomics 2011;8:13-27. 


\section{Cellular Physiology Cell Physiol Biochem 2017;43:257-270

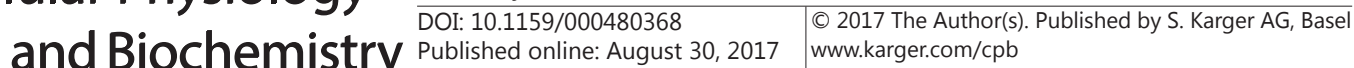

Warnke et al.: Thyroid Cells on the Random Positioning Machine

3 Rea G, Cristofaro F, Pani G, Pascucci B, Ghuge SA, Corsetto PA, Imbriani M, Visai L, Rizzo AM: Microgravitydriven remodeling of the proteome reveals insights into molecular mechanisms and signal networks involved in response to the space flight environment. J Proteomics 2016;137:3-18.

4 Albi E, Curcio F, Lazzarini A, Floridi A, Cataldi S, Lazzarini R, Loreti E, Ferri I, Ambesi-Impiombato FS: How microgravity changes galectin-3 in thyroid follicles. Biomed Res Int 2014;2014:652863.

-5 Masini MA, Albi E, Barmo C, Bonfiglio T, Bruni L, Canesi L, Cataldi S, Curcio F, D'Amora M, Ferri I, Goto K, Kawano F, Lazzarini R, Loreti E, Nakai N, Ohira T, Ohira Y, Palmero S, Prato P, Ricci F, Scarabelli L, Shibaguchi T, Spelat R, Strollo F, Ambesi-Impiombato FS: The impact of long-term exposure to space environment on adult mammalian organisms: a study on mouse thyroid and testis. PLoS One 2012;7:e35418.

6 Pietsch J, Ma X, Wehland M, Aleshcheva G, Schwarzwalder A, Segerer J, Birlem M, Horn A, Bauer J, Infanger M, Grimm D: Spheroid formation of human thyroid cancer cells in an automated culturing system during the Shenzhou-8 Space mission. Biomaterials 2013;34:7694-7705.

7 Ma X, Pietsch J, Wehland M, Schulz H, Saar K, Hubner N, Bauer J, Braun M, Schwarzwalder A, Segerer J, Birlem M, Horn A, Hemmersbach R, Wasser K, Grosse J, Infanger M, Grimm D: Differential gene expression profile and altered cytokine secretion of thyroid cancer cells in space. FASEB J 2014;28:813-835.

-8 Grosse J, Wehland M, Pietsch J, Schulz H, Saar K, Hubner N, Eilles C, Bauer J, Abou-El-Ardat K, Baatout S, Ma $\mathrm{X}$, Infanger M, Hemmersbach R, Grimm D: Gravity-sensitive signaling drives 3-dimensional formation of multicellular thyroid cancer spheroids. FASEB J 2012;26:5124-5140.

-9 Riwaldt S, Pietsch J, Sickmann A, Bauer J, Braun M, Segerer J, Schwarzwalder A, Aleshcheva G, Corydon TJ, Infanger M, Grimm D: Identification of proteins involved in inhibition of spheroid formation under microgravity. Proteomics 2015;15:2945-2952.

$>10$ Riwaldt S, Bauer J, Pietsch J, Braun M, Segerer J, Schwarzwalder A, Corydon TJ, Infanger M, Grimm D: The Importance of Caveolin-1 as Key-Regulator of Three-Dimensional Growth in Thyroid Cancer Cells Cultured under Real and Simulated Microgravity Conditions. Int J Mol Sci 2015;16:28296-28310.

11 Bauer J, Wehland M, Pietsch J, Sickmann A, Weber G, Grimm D: Annotated Gene and Proteome Data Support Recognition of Interconnections Between the Results of Different Experiments in Space Research. Microgravity Sci Technol 2016;28:357-365.

12 Grimm D, Bauer J, Kossmehl P, Shakibaei M, Schoberger J, Pickenhahn H, Schulze-Tanzil G, Vetter R, Eilles C, Paul M, Cogoli A: Simulated microgravity alters differentiation and increases apoptosis in human follicular thyroid carcinoma cells. FASEB J 2002;16:604-606.

13 Brungs S, Egli M, Wuest SL, M. Christianen PC, W. A. van Loon JJ, Ngo Anh TJ, Hemmersbach R: Facilities for Simulation of Microgravity in the ESA Ground-Based Facility Programme. Microgravity Sci Technol 2016;28:191-203.

14 Warnke E, Kopp S, Wehland M, Hemmersbach R, Bauer J, Pietsch J, Infanger M, Grimm D: Thyroid Cells Exposed to Simulated Microgravity Conditions - Comparison of the Fast Rotating Clinostat and the Random Positioning Machine. Microgravity Sci Technol 2016;28:247-260.

15 Hanley P, Lord K, Bauer AJ: Thyroid Disorders in Children and Adolescents: A Review. JAMA Pediatr 2016;170:1008-1019.

16 Ito K, Kagaya Y, Shimokawa H: Thyroid hormone and chronically unloaded hearts. Vascul Pharmacol 2010;52:138-141.

17 Martin A, Zhou A, Gordon RE, Henderson SC, Schwartz AE, Schwartz AE, Friedman EW, Davies TF: Thyroid organoid formation in simulated microgravity: influence of keratinocyte growth factor. Thyroid 2000;10:481-487.

18 Albi E, Ambesi-Impiombato FS, Peverini M, Damaskopoulou E, Fontanini E, Lazzarini R, Curcio F, Perrella G: Thyrotropin receptor and membrane interactions in FRTL-5 thyroid cell strain in microgravity. Astrobiology 2011;11:57-64.

19 Albi E, Curcio F, Lazzarini A, Floridi A, Cataldi S, Lazzarini R, Loreti E, Ferri I, Ambesi-Impiombato FS: A firmer understanding of the effect of hypergravity on thyroid tissue: cholesterol and thyrotropin receptor. PLoS One 2014;9:e98250.

-20 Pietsch J, Sickmann A, Weber G, Bauer J, Egli M, Wildgruber R, Infanger M, Grimm D: A proteomic approach to analysing spheroid formation of two human thyroid cell lines cultured on a random positioning machine. Proteomics 2011;11:2095-2104. 


\section{Cellular Physiology Cell Physiol Biochem 2017;43:257-270

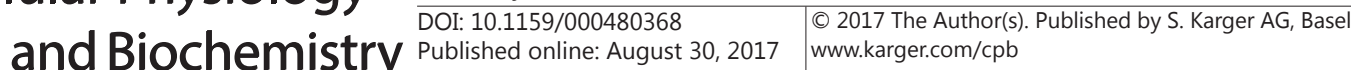 \\ Warnke et al.: Thyroid Cells on the Random Positioning Machine}

-21 Kopp S, Warnke E, Wehland M, Aleshcheva G, Magnusson NE, Hemmersbach R, Corydon TJ, Bauer J, Infanger M, Grimm D: Mechanisms of three-dimensional growth of thyroid cells during long-term simulated microgravity. Sci Rep 2015;5:16691.

22 Lemoine NR, Mayall ES, Jones T, Sheer D, McDermid S, Kendall-Taylor P, Wynford-Thomas D: Characterisation of human thyroid epithelial cells immortalised in vitro by simian virus 40 DNA transfection. Br J Cancer 1989;60:897-903.

23 Borst AG, van Loon JJWA: Technology and Developments for the Random Positioning Machine, RPM. Microgravity Sci Technol 2008;21:287-292.

-24 Grimm D, Infanger M, Westphal K, Ulbrich C, Pietsch J, Kossmehl P, Vadrucci S, Baatout S, Flick B, Paul M, Bauer J: A delayed type of three-dimensional growth of human endothelial cells under simulated weightlessness. Tissue Eng Part A 2009;15:2267-2275.

25 Grimm D, Bauer J, Ulbrich C, Westphal K, Wehland M, Infanger M, Aleshcheva G, Pietsch J, Ghardi M, Beck M, El-Saghire H, de Saint-Georges L, Baatout S: Different responsiveness of endothelial cells to vascular endothelial growth factor and basic fibroblast growth factor added to culture media under gravity and simulated microgravity. Tissue Eng Part A 2010;16:1559-1573.

-26 Grosse J, Warnke E, Pohl F, Magnusson NE, Wehland M, Infanger M, Eilles C, Grimm D: Impact of sunitinib on human thyroid cancer cells. Cell Physiol Biochem 2013;32:154-170.

27 Infanger M, Ulbrich C, Baatout S, Wehland M, Kreutz R, Bauer J, Grosse J, Vadrucci S, Cogoli A, Derradji H, Neefs M, Kusters S, Spain M, Paul M, Grimm D: Modeled gravitational unloading induced downregulation of endothelin-1 in human endothelial cells. J Cell Biochem 2007;101:1439-1455.

-28 Warnke E, Pietsch J, Wehland M, Bauer J, Infanger M, Gorog M, Hemmersbach R, Braun M, Ma X, Sahana J, Grimm D: Spheroid formation of human thyroid cancer cells under simulated microgravity: a possible role of CTGF and CAV1. Cell Commun Signal 2014;12:32.

-29 Grosse J, Warnke E, Wehland M, Pietsch J, Pohl F, Wise P, Magnusson NE, Eilles C, Grimm D: Mechanisms of apoptosis in irradiated and sunitinib-treated follicular thyroid cancer cells. Apoptosis 2014;19:480-490.

-30 Infanger M, Faramarzi S, Grosse J, Kurth E, Ulbrich C, Bauer J, Wehland M, Kreutz R, Kossmehl P, Paul M, Grimm D: Expression of vascular endothelial growth factor and receptor tyrosine kinases in cardiac ischemia/reperfusion injury. Cardiovasc Pathol 2007;16:291-299.

31 Kossmehl P, Kurth E, Faramarzi S, Habighorst B, Shakibaei M, Wehland M, Kreutz R, Infanger M, AH JD, Grosse J, Paul M, Grimm D: Mechanisms of apoptosis after ischemia and reperfusion: role of the reninangiotensin system. Apoptosis 2006;11:347-358.

-32 Rothermund L, Kreutz R, Kossmehl P, Fredersdorf S, Shakibaei M, Schulze-Tanzil G, Paul M, Grimm D: Early onset of chondroitin sulfate and osteopontin expression in angiotensin II-dependent left ventricular hypertrophy. Am J Hypertens 2002;15:644-652.

33 Kopp S, Slumstrup L, Corydon TJ, Sahana J, Aleshcheva G, Islam T, Magnusson NE, Wehland M, Bauer J, Infanger M, Grimm D: Identifications of novel mechanisms in breast cancer cells involving ductlike multicellular spheroid formation after exposure to the Random Positioning Machine. Sci Rep 2016;6:26887.

-34 Green JA, Berrier AL, Pankov R, Yamada KM: beta1 integrin cytoplasmic domain residues selectively modulate fibronectin matrix assembly and cell spreading through talin and Akt-1. J Biol Chem 2009;284:8148-8159.

-35 Ichikawa-Tomikawa N, Ogawa J, Douet V, Xu Z, Kamikubo Y, Sakurai T, Kohsaka S, Chiba H, Hattori N, Yamada Y, Arikawa-Hirasawa E: Laminin alpha1 is essential for mouse cerebellar development. Matrix Biol 2012;31:17-28.

-36 Jung KK, Liu XW, Chirco R, Fridman R, Kim HR: Identification of CD63 as a tissue inhibitor of metalloproteinase-1 interacting cell surface protein. EMBO J 2006;25:3934-3942.

37 Xie K: Interleukin-8 and human cancer biology. Cytokine Growth Factor Rev 2001;12:375-391.

38 Shao B, Yago T, Coghill PA, Klopocki AG, Mehta-D'souza P, Schmidtke DW, Rodgers W, McEver RP: Signaldependent slow leukocyte rolling does not require cytoskeletal anchorage of P-selectin glycoprotein ligand-1 (PSGL-1) or integrin alphaLbeta2. J Biol Chem 2012;287:19585-19598.

39 Ariel A, Hershkoviz R, Cahalon L, Williams DE, Akiyama SK, Yamada KM, Chen C, Alon R, Lapidot T, Lider O: Induction of $\mathrm{T}$ cell adhesion to extracellular matrix or endothelial cell ligands by soluble or matrix-bound interleukin-7. Eur J Immunol 1997;27:2562-2570. 


\section{Cellular Physiology Cell Physiol Biochem 2017;43:257-270

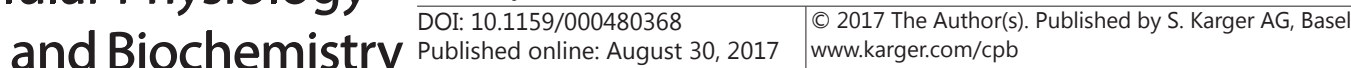

40 Mitsi M, Hong Z, Costello CE, Nugent MA: Heparin-mediated conformational changes in fibronectin expose vascular endothelial growth factor binding sites. Biochemistry 2006;45:10319-10328.

-41 Zhang GJ, Crist SA, McKerrow AK, Xu Y, Ladehoff DC, See WA: Autocrine IL-6 production by human transitional carcinoma cells upregulates expression of the alpha5beta1 firbonectin receptor. J Urol 2000;163:1553-1559.

42 Suhr KB, Tsuboi R, Seo EY, Piao YJ, Lee JH, Park JK, Ogawa H: Sphingosylphosphorylcholine stimulates cellular fibronectin expression through upregulation of IL-6 in cultured human dermal fibroblasts. Arch Dermatol Res 2003;294:433-437.

-43 Giunti S, Tesch GH, Pinach S, Burt DJ, Cooper ME, Cavallo-Perin P, Camussi G, Gruden G: Monocyte chemoattractant protein-1 has prosclerotic effects both in a mouse model of experimental diabetes and in vitro in human mesangial cells. Diabetologia 2008;51:198-207.

44 Ashida N, Arai H, Yamasaki M, Kita T: Distinct signaling pathways for MCP-1-dependent integrin activation and chemotaxis. J Biol Chem 2001;276:16555-16560.

45 Ancelin M, Chollet-Martin S, Herve MA, Legrand C, El Benna J, Perrot-Applanat M: Vascular endothelial growth factor VEGF189 induces human neutrophil chemotaxis in extravascular tissue via an autocrine amplification mechanism. Lab Invest 2004;84:502-512.

46 Mohamed MM: Monocytes conditioned media stimulate fibronectin expression and spreading of inflammatory breast cancer cells in three-dimensional culture: A mechanism mediated by IL-8 signaling pathway. Cell Commun Signal 2012;10:3.

47 Lee TH, Avraham H, Lee SH, Avraham S: Vascular endothelial growth factor modulates neutrophil transendothelial migration via up-regulation of interleukin-8 in human brain microvascular endothelial cells. J Biol Chem 2002;277:10445-10451.

48 Heinrich PC, Behrmann I, Haan S, Hermanns HM, Muller-Newen G, Schaper F: Principles of interleukin (IL)6-type cytokine signalling and its regulation. Biochem J 2003;374:1-20.

49 Svejgaard B, Wehland M, Ma X, Kopp S, Sahana J, Warnke E, Aleshcheva G, Hemmersbach R, Hauslage J, Grosse J, Bauer J, Corydon TJ, Islam T, Infanger M, Grimm D: Common Effects on Cancer Cells Exerted by a Random Positioning Machine and a 2D Clinostat. PLoS One 2015;10:e0135157.

-50 Nikitovic D, Juranek I, Wilks MF, Tzardi M, Tsatsakis A, Tzanakakis GN: Anthracycline-dependent cardiotoxicity and extracellular matrix remodeling. Chest 2014;146:1123-1130.

51 Damas JK, Waehre T, Yndestad A, Otterdal K, Hognestad A, Solum NO, Gullestad L, Froland SS, Aukrust P: Interleukin-7-mediated inflammation in unstable angina: possible role of chemokines and platelets. Circulation 2003;107:2670-2676.

52 Kobawala TP, Trivedi TI, Gajjar KK, Patel DH, Patel GH, Ghosh NR: Significance of Interleukin-6 in Papillary Thyroid Carcinoma. J Thyroid Res 2016;2016:6178921.

53 Kumari N, Dwarakanath BS, Das A, Bhatt AN: Role of interleukin-6 in cancer progression and therapeutic resistance. Tumour Biol 2016;9: 11553-11572.

54 Shi J, Wei PK: Interleukin-8: A potent promoter of angiogenesis in gastric cancer. Oncol Lett 2016;11:10431050 .

55 Mihara M, Hashizume M, Yoshida H, Suzuki M, Shiina M: IL-6/IL-6 receptor system and its role in physiological and pathological conditions. Clin Sci (Lond) 2012;122:143-159.

56 Singh JK, Simoes BM, Howell SJ, Farnie G, Clarke RB: Recent advances reveal IL-8 signaling as a potential key to targeting breast cancer stem cells. Breast Cancer Res 2013;15:210.

-57 Tartour E, Pere H, Maillere B, Terme M, Merillon N, Taieb J, Sandoval F, Quintin-Colonna F, Lacerda K, Karadimou A, Badoual C, Tedgui A, Fridman WH, Oudard S: Angiogenesis and immunity: a bidirectional link potentially relevant for the monitoring of antiangiogenic therapy and the development of novel therapeutic combination with immunotherapy. Cancer Metastasis Rev 2011;30:83-95.

58 Provatopoulou X, Georgiadou D, Sergentanis TN, Kalogera E, Spyridakis J, Gounaris A, Zografos GN: Interleukins as markers of inflammation in malignant and benign thyroid disease. Inflamm Res 2014;63:667-674.

59 Zarogoulidis P, Lampaki S, Yarmus L, Kioumis I, Pitsiou G, Katsikogiannis N, Hohenforst-Schmidt W, Li Q Huang H, Sakkas A, Organtzis J, Sakkas L, Mpoukovinas I, Tsakiridis K, Lazaridis G, Syrigos K, Zarogoulidis K: Interleukin-7 and interleukin-15 for cancer. J Cancer 2014;5:765-773.

-60 Jiang Q, Li WQ Aiello FB, Mazzucchelli R, Asefa B, Khaled AR, Durum SK: Cell biology of IL-7, a key lymphotrophin. Cytokine Growth Factor Rev 2005;16:513-533. 


\section{Cellular Physiology Cell Physiol Biochem 2017;43:257-270

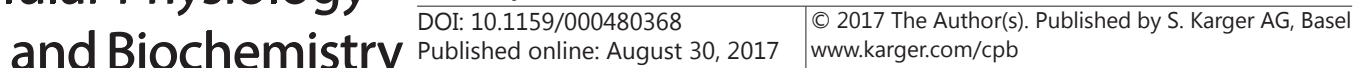

Warnke et al.: Thyroid Cells on the Random Positioning Machine

-61 Kirnbauer R, Charvat B, Schauer E, Kock A, Urbanski A, Forster E, Neuner P, Assmann I, Luger TA, Schwarz T: Modulation of intercellular adhesion molecule-1 expression on human melanocytes and melanoma cells: evidence for a regulatory role of IL-6, IL-7, TNF beta, and UVB light. J Invest Dermatol 1992;98:320-326.

62 Yamanaka O, Saika S, Ikeda K, Miyazaki K, Ohnishi Y, Ooshima A: Interleukin-7 modulates extracellular matrix production and TGF-beta signaling in cultured human subconjunctival fibroblasts. Curr Eye Res 2006;31:491-499.

-63 Hynes RO: Integrins: bidirectional, allosteric signaling machines. Cell 2002;110:673-687.

-64 Kubow KE, Horwitz AR: Reducing background fluorescence reveals adhesions in 3D matrices. Nat Cell Biol 2011;13:3-5.

65 Yin HL, Wu CC, Lin CH, Chai CY, Hou MF, Chang SJ, Tsai HP, Hung WC, Pan MR, Luo CW: beta1 Integrin as a Prognostic and Predictive Marker in Triple-Negative Breast Cancer. Int J Mol Sci 2016;17: 1432.

66 Liang W, Zhu C, Liu F, Cui W, Wang Q, Chen Z, Zhou Q, Xu S, Zhai C, Fan W: Integrin beta1 Gene Therapy Enhances in Vitro Creation of Tissue-Engineered Cartilage Under Periodic Mechanical Stress. Cell Physiol Biochem 2015;37:1301-1314.

67 Aleshcheva G, Wehland M, Sahana J, Bauer J, Corydon TJ, Hemmersbach R, Frett T, Egli M, Infanger M, Grosse J, Grimm D: Moderate alterations of the cytoskeleton in human chondrocytes after short-term microgravity produced by parabolic flight maneuvers could be prevented by up-regulation of BMP-2 and SOX-9. FASEB J 2015;29:2303-2314.

68 Savino W, Mendes-da-Cruz DA, Golbert DC, Riederer I, Cotta-de-Almeida V: Laminin-Mediated Interactions in Thymocyte Migration and Development. Front Immunol 2015;6:579.

69 Bauer J, Kopp S, Schlagberger EM, Grosse J, Sahana J, Riwaldt S, Wehland M, Luetzenberg R, Infanger M, Grimm D: Proteome Analysis of Human Follicular Thyroid Cancer Cells Exposed to the Random Positioning Machine. Int J Mol Sci 2017;18: 546.

70 Kim TO, Park SH, Kim HS, Ahuja N, Yi JM: DNA methylation changes in extracellular remodeling pathway genes during the transformation of human mesenchymal stem cells. Genes Genomics 2016;38:611-619.

71 Vignoud L, Albiges-Rizo C, Frachet P, Block MR: NPXY motifs control the recruitment of the alpha5beta1 integrin in focal adhesions independently of the association of talin with the beta1 chain. J Cell Sci 1997;110:1421-1430.

72 Grimm D, Bauer J, Schoenberger J: Blockade of neoangiogenesis, a new and promising technique to control the growth of malignant tumors and their metastases. Curr Vasc Pharmacol 2009;7:347-357.

73 Hu K, Olsen BR: Vascular endothelial growth factor control mechanisms in skeletal growth and repair. Dev Dyn 2017;246:227-234.

74 Pożarowska D, Pożarowski P: The era of anti-vascular endothelial growth factor (VEGF) drugs in ophthalmology, VEGF and anti-VEGF therapy. Cent Eur J Immunol 2016;41:311-316.

75 Wehland M, Bauer J, Magnusson NE, Infanger M, Grimm D: Biomarkers for anti-angiogenic therapy in cancer. Int J Mol Sci 2013;14:9338-9364.

76 Jackson HW, Defamie V, Waterhouse P, Khokha R: TIMPs: versatile extracellular regulators in cancer. Nat Rev Cancer 2017;17:38-53.

-77 Verma RP, Hansch C: Matrix metalloproteinases (MMPs): Chemical-biological functions and (Q)SARs. Bioorg Med Chem 2007;15:2223-2268.

78 Jurczak P, Groves P, Szymanska A, Rodziewicz-Motowidlo S: Human cystatin C monomer, dimer, oligomer, and amyloid structures are related to health and disease. FEBS Lett 2016;590:4192-4201.

-79 Deshmane SL, Kremlev S, Amini S, Sawaya BE: Monocyte Chemoattractant Protein-1 (MCP-1): An Overview. J Interferon Cytokine Res 2009;29:313-326.

80 Gerard C, Rollins BJ: Chemokines and disease. Nat Immunol 2001;2:108-115.

81 Rudemiller NP, Crowley SD: The role of chemokines in hypertension and consequent target organ damage. Pharmacol Res 2017;119:404-411.

82 Yoshimura T: The production of monocyte chemoattractant protein-1 (MCP-1)/CCL2 in tumor microenvironments. Cytokine DOI:10.1016/j.cyto.2017.02.001.

83 Vakilian A, Khorramdelazad H, Heidari P, Sheikh Rezaei Z, Hassanshahi G: CCL2/CCR2 signaling pathway in glioblastoma multiforme. Neurochem Int 2017;103:1-7. 